\title{
Weronika Gadzicka
}

ORCID: 0000-0002-9068-9723

Jagiellonian University

DOI: $10.19195 / 1733-5779.29 .12$

\section{Legal and formal analysis of chosen provisions of Directive 2009/30/EC and of the Act of 25 August 2006 on the fuel quality monitoring and control system}

\section{JEL Classification: K32}

Keywords: National Reduction Target, greenhouse gas emission reduction, energy, energy companies

Słowa kluczowe: Narodowy Cel Redukcyjny, redukcja emisji gazów cieplarnianych, energia, spółki energetyczne

Abstract: The Directive 2009/30/EC and the Polish Act on the fuel quality monitoring and control system imposes a duty on the entities fulfilling the National Reduction Target (NRT) to reduce emissions of greenhouse gases to $6 \%$. The reduction target of at least $6 \%$ cannot be spread over the entire fuel market. It applies to every entity implementing the NRT separately. Member States, as well as the fuel market, are not responsible for not achieving the reduction target. This responsibility is limited to individual business entities implementing the NRT and concerns the fulfilment of the reduction target and the providing of the report on the implementation of the reduction target. It is necessary to carry out technical and economic analyses, the subject of which should be to answer the question of whether the entities realising the NRT are able to predict the potential amount of the fine that may be imposed on them based on Art. 35c section 3 of the Act.

\section{Analiza prawna i formalna wybranych przepisów dyrektywy 2009/30/WE i ustawy z dnia 25 sierpnia 2006 roku o systemie monitorowania i kontroli jakości paliw}

\footnotetext{
Abstrakt: Dyrektywa 2009/30/WE oraz ustawa o systemie monitorowania i kontroli jakości paliw nakładają na podmioty spełniające Narodowy Cel Redukcyjny obowiązek obniżenia emisji gazów cieplarnianych do $6 \%$. Cel redukcji wynoszący co najmniej $6 \%$ nie może być rozłożony na cały rynek
} 
paliw — dotyczy to każdego podmiotu wdrażającego NCR oddzielnie. Państwa członkowskie, jak też rynek paliw nie ponoszą odpowiedzialności w wypadku nieosiągnięcia tegoż celu redukcyjnego. Odpowiedzialność ta jest ograniczona do poszczególnych podmiotów gospodarczych realizujących NCR i dotyczy realizacji celu redukcyjnego oraz dostarczenia sprawozdania z realizacji NCR. Konieczne jest przeprowadzenie analiz technicznych i ekonomicznych, których przedmiotem powinno być udzielenie odpowiedzi na pytanie, czy podmioty realizujące NRT są w stanie przewidzieć potencjalną kwotę grzywny, jaka może zostać na nie nałożona na podstawie art. 35c ust. 3 ustawy.

The aim of the Act of 25 August 2006 on the fuel quality monitoring and control system ${ }^{1}$ and the Directive 2009/30/EC of the European Parliament and of the Council of 23 April $2009^{2}$ (hereinafter as "the Directive") is to reduce the emissions of greenhouse gases to reach a $6 \%$ limit and to effectively monitor the emissions of greenhouse gases.

This piece will analyse chosen aspects of these regulations taking into consideration its legal and formal aspects. The analysed aspects will be: the obligation to implement the National Reduction Target, the obligation of annual reports provided by the entities fulfilling the National Reduction Target, the possibility of joint realisation of the National Reduction Target by a group of entities, consequences of the lack of fulfilment of the National Reduction Target and penalties for this, the principle of definite penalties as well as additional problems indicated by one of the entities fulfilling the National Reduction Target.

\section{Obligation to implement the reduction of greenhouse gas emissions target of $6 \%$}

The regulation regarding the obligation to limit greenhouse gas emissions by reducing greenhouse gas emissions in the life cycle of transport fuels by $6 \%$ is described in Art. 30b section 1 of the Act of 25 August 2006 on the fuel quality monitoring and control system (hereinafter as "the Act.") The National Reduction Target (hereinafter referred to as "the NRT") is imposed upon every entity required to implement the NRT, which, as per definition provided in Art. 2 section 1 subsection 29, is:

1. Any entity, including those with their registered office or place of residence outside the territory of the Republic of Poland, conducting, independently or through another entity, production, import or intra-community acquisition of liquid fuels, liquid biofuels, liquefied gas (LPG), compressed natural gas $(\mathrm{CNG})$, liquefied gas natural gas (LNG) or oil for inland waterway engines that:

${ }^{1}$ Act of 25 August 2006 on the fuel quality monitoring and control system (i.e. Journal of Laws of 2019, item 660).

${ }^{2}$ Directive 2009/30/EC of the European Parliament and of the Council of 23 April 2009 amending Directive 98/70/EC as regards the specification of petrol, diesel and gas-oil and introducing a mechanism to monitor and reduce greenhouse gas emissions and amending Council Directive 1999/32/EC as regards the specification of fuel used by inland waterway vessels and repealing Directive 93/12/EEC. 
a) dispose of them on the territory of the Republic of Poland by making any legal or factual action, or

b) consumes them for own needs on the territory of the Republic of Poland, excluding the import of liquid fuels intended for use during transport and imported in standard tanks, referred to in art. 33 section 1 of the Act of 6 December 2008 on excise duty (Journal of Laws of 2018 item 1114, as amended);

2. energy company, within the meaning of the provisions of the Act of 10 April 1997 - Energy Law (Journal of Laws of 2018 item 755, as amended), carrying out economic activity in the field of providing electricity used in motor vehicles in meaning of the provisions of the Act of 20 June 1997 - Road Traffic Law, after informing the President of the Energy Regulatory Office about the acceptance of the obligation referred to in art. $30 \mathrm{~b}$ par. 1 ;

3. any entity, including those with their registered office or place of residence outside the territory of the Republic of Poland, conducting, alone or through another entity, production, import or purchase of intra-community aviation gasoline and gasoline or oil for jet engines used in aircraft, after informing the President of the Energy Regulatory Office about the acceptance of the obligation referred to in art. $30 \mathrm{~b}$ par. 1 which:

a) disposes of them on the territory of the Republic of Poland by making any legal or factual action, or

b) consumes them for own needs on the territory of the Republic of Poland, excluding the import of liquid fuels intended for use during transport and imported in standard tanks, referred to in art. 33 para. 1 of the Act of 6 December 2008 on excise duty.

In connection with the above-mentioned provisions, this obligation is imposed on each of the entities individually and does not apply to the entire fuel market. However, only the first described entity is obliged to implement the NRT unconditionally and the latter two entities, entities providing electricity for motor vehicles and entities providing gasoline or oil for jet engines, can do so voluntarily, after informing the President of the Energy Regulatory Office (hereinafter as "the President of ERO") about the acceptance of the obligation.

To my understanding, the voluntariness of accepting the obligation by the entities providing electricity for motor vehicles is available due to the fact that these entities already provide environmentally-friendly products and services that reduce greenhouse gas emissions drastically. As to the entities providing gasoline or oil for jet engines, the reasons for exclusion might be more problematic. It is definitely not because they are already being eco-friendly, but to the contrary, because aircraft cannot be fuelled by any other source of energy equally effective as that currently used. Also, travelling by aircraft cannot be easily replaced with any other means of transport and this will only be more and more popular in the coming years.

\section{Obligation to provide annual reports to the President of the Energy Regulatory Office}

Another requirement imposed on entities implementing the NRT, pursuant to Art. $30 \mathrm{i}$ of the Act, is to present annual reports to the President of the Energy 
Regulatory Office aimed at demonstrating the implementation of reduction of greenhouse gas emissions by individual entities implementing the NRT.

Additionally, Art. 35a section 8 of the Act gives the basis for imposing a fine on entities implementing the NCR, which do not submit the annual reports defining the implementation of the reduction target on time. This penalty is also imposed by the President of the ERO and amounts to PLN 5,000 as provided in Art. 35c section 1 of the Act. The penalty seems to not be very harsh, severe or dissuasive, which are the principles of a penalty, and in my opinion huge companies from the energy sector might be willing to pay the fine instead of taking more workload in order to prepare the report.

Moreover, according to the report provided by Orlen "The National Reduction Target from the perspective of the entity obliged to implement it" 3 the system of reporting on raw materials used for the production of each batch of imported fuel will result in the need to expand the central administration of Member States, as well as additional positions in companies in order to prepare and verify reduction reports.

\section{Joint NRT implementation}

Individual entities implementing the NRT may, in order to reduce the severity of obligations under the Act, in accordance with Art. 30d section 1, carry out these duties jointly. In order to do so, the President of the ERO should be informed about the joint performance of obligations. The notification shall include register information and information relevant for tax purposes of each entity, the type of activity performed by each entity and a statement on the truthfulness of the information. The duties that can be jointly performed include: ensuring a minimum reduction of greenhouse gases of $6 \%$ per Art. $30 \mathrm{~b}$ section 1 of the Act and submitting a joint annual report referred to in Art. $30 \mathrm{i}$ section 1 of the Act.

However, it should be pointed out that if the entities jointly perform the obligations to achieve the reduction target fail to perform those obligations, only the entity that failed to fulfil this obligation is punished pursuant to Art. $35 \mathrm{~b}$ section 2 of the Act. In addition, if the entities stated that they will jointly submit the report referred to in Art. 30i section 1 of the Act, and these obligations will not be performed, a fine of PLN 5,000 will be imposed on the entity that was designated as responsible for submitting the annual report.

This opportunity seems to be very helpful for the entities fulfilling the NRT, as entities managing to reach less than $6 \%$ of the greenhouse gas emission indicator and those not meeting the requirement can mitigate the differences and jointly be

${ }^{3}$ P. Szpakowski, "Narodowy Cel Redukcyjny z perspektywy podmiotu zobligowanego do jego realizacji," https://docplayer.pl/10486856-Narodowy-cel-redukcyjny-z-perspektywy-podmiotu-zobligowanego-do-jego-realizacji.html (accessed: 23.06.2019). 
able to fulfil the NRT. Furthermore, if the obligation is not met, it seems to be very reasonable that the entity responsible for failing to fulfil the obligation is the one being punished and not the whole group.

\section{Lack of fulfilment of the NRT obligation and fines}

Both individual Member States and the fuel market in a given Member State have no negative consequences for not achieving the reduction target. Possible consequences or responsibilities concern individual entities implementing NRT and concern both failure to realise the reduction target as well as non-performance of the information obligation, i.e. timely submission of the report referred to in Art. $30 \mathrm{i}$ sec. 1 of the Act.

Article 35a section 7 of the Act indicates that entities carrying out the NRT and have not fulfilled the reduction obligation will be imposed by the President of the ERO with a fine, however it may not exceed $15 \%$ of the revenue of the punished entity achieved in the previous tax year as to the Art. 35c section 4 .

While analysing the issues of failure to achieve the NRT by EU Member States, the effects of the possible failure to achieve the reduction target of $6 \%$ and the impact of not meeting the reduction target of fuel suppliers should be analysed in accordance with Art. 7a (2) a) of the Directive and regarded as a responsibility of a Member State. It should be considered whether this liability can result only from the fact that the goal has not been achieved, or whether the failure to implement the necessary means to achieve it should also be considered.

In accordance with Art. 288 of the Treaty of the Functioning of the European Union ("TFEU") 4 the Directive binds each country to which it is addressed in relation to the result that is to be achieved, but leaves the national authorities the freedom to choose the form and means. The provision constituting the legal basis and the starting point for the obligation to implement directives is Art. 4 Treaty on the European Union ("TEU") 5 which imposes a broad obligation on the Member States to cooperate in achieving the Union's objectives by ensuring full effectiveness of Union law. Considering the implementation of directives in the light of their socio-economic objective, it should be noted that Art. 7a (2) a) of the Directive understood literally will lead to the conclusion that the Directive only imposes an obligation on the Member State to introduce a requirement for a gradual reduction of greenhouse gas emissions by suppliers by $6 \%$. Correct transposition of such an obligation in the literal sense would be limited only to the introduction of the above requirement of achieving the reduction goal and to guard it with appropriately severe sanctions.

\footnotetext{
${ }^{4}$ Consolidated versions of the Treaty on European Union and the Treaty on the Functioning of the European Union (2012/C 326/01).

${ }^{5}$ Ibidem.
} 
However, in the light of the above considerations, such an interpretation of the obligation to transpose might be overly simplified and would lead to a misunderstanding of the concept of a directive which is aimed at achieving certain objectives. Such an objective in the sense of the Directive under consideration is not the introduction of regulations that force entrepreneurs to reduce gas emissions, but actually limit these emissions. Moreover, there are punitive fines for not fulfilling the obligation under the NRT even if the deviations are very small.

\section{Principle of specificity of punishment}

In regard to the abovementioned penalties imposed by the Act, the aspect of the formula for calculating the amount of the penalty for non-compliance with the NCR included in Art. 35c section 3 of the Act should be analysed. Due to the significant complexity of calculating issues for determining the amount of the fine, the question should be asked whether it is possible to predict the probable amount of the fine in the event of non-compliance with the obligation under Art. 30b section 1 of the Act at all or to a certain extent, and if so whether it is possible to predict it in the period before the end of a given calendar year. The question of the specificity of punishment appears in Polish law mainly in the context of criminal law. By analogy, the legal principles and interpretative norms introduced by the Constitutional Tribunal may apply in this respect, which has been confirmed, in the jurisprudence of administrative courts. ${ }^{6}$

The Constitutional Tribunal ${ }^{7}$ indicates that the indeterminacy of crime may be introduced by the legislator by making a conscious description of a crime that is precise but at the same time so wide that its literal use is not possible and the choice of cases in which criminal liability should occur is to be decided by law enforcement authorities and courts. It is obvious that in a law-abiding state, criminal laws which the legislator cannot formulate precisely or has no chance to make to the Supreme Court's case-law should not apply. The legislator cannot require the citizen to become aware of the scope of the criminal prohibition and to comply with it, if he is not able to clearly define its limits. ${ }^{8}$

In addition, the Constitutional Tribunal states that

the requirement of specificity must apply both to the material elements of the act and to the elements of the punishment, so that it would satisfy the requirement of predictability. The law provides for the citizens (the subjects of criminal liability) the possibility of prior and accurate assessment of the consequences of their behaviour. The material elements of a punishable act are deemed to be defined in

${ }^{6}$ Judgment of the Voivodship Administrative Court in Warsaw of 18 November 2011, Ref. file: VI SA/Wa 1425/11 and Order of the Voivodship Administrative Court in Warsaw of 27 June 2013, Ref. file: VI SA/Wa 946/13 and Judgment of the Supreme Administrative Court of 24 February 2011, Ref. file: II GSK 257/10.

7 Judgment of the Constitutional Tribunal of 5 May 2004, Ref. file: P 2/03.

${ }^{8}$ L. Gardocki, Prawo karne, 9th ed., Warzsawa 2003, p. 16. 
the act (in accordance with the constitutional principle of exclusivity of the acts) in a complete, precise and unambiguous manner. ${ }^{9}$

The above means that the regulations must be constructed in such a way that it is possible to deduce from the legal (administrative) norm contained in the act to which person the order or prohibition is addressed, what are the features of the punished act and what is the penalty for committing this act.

In the present case, there is no doubt as to what is penalised under Art. 35c section 3 of the Act, because the provision explicitly specifies that the entity pursuing the National Reduction Target is penalised when it fails to fulfil the obligation provided in Art. 30b section 1 of the Act: failure to provide the minimum value of reducing greenhouse gas emissions in the life cycle of liquid fuels, liquid biofuels, liquefied gas (LPG), compressed natural gas (CNG), liquefied natural gas (LNG) or oil for inland waterway engines, used in transport, per unit of energy available for any legal or actual use, or consumed by it for one's own use, and for electricity used in motor vehicles sold to the end user or consumed by the entity for one's own needs, amounting to $6 \%$.

At the same time, the Constitutional Tribunal ${ }^{10}$ clearly indicates that the principle of specificity of punishment (nulla poena sine lege) has the character of an independent constitutional guarantee, although it is strictly functionally connected with the principle nullum crimen sine lege in the sense that the determination of any behaviour as a prohibited act requires in each case to also simultaneously determine the penalty for this act. The principle of nulla poena sine lege requires "the proper determination of the punishment by the legislator." The act must define the elements constituting the penalty in order to give them a whole picture of how constitutional rights and freedoms are constrained by the legislator as a punishment. It must meet the test of predictability, and therefore the entity must be provided with the opportunity to identify, on the basis of the act, the essential elements of punishment, i.e. the manner and nature of restricting constitutional rights or freedoms constituting the essence of reaction to committing a prohibited act. ${ }^{11}$

The Tribunal's case-law explicitly states that elements concerning the specificity of punishment must be formulated in a complete, precise and unambiguous manner. However, there are no contraindications to present the amount of a fine by means of a mathematical formula indicated in the act, except that it is necessary to analyse whether it is possible to determine the amount of the penalty threatening the given entity. The Constitutional Tribunal explicitly emphasises that this principle of the specificity of punishment (nulla poena sine lege) should serve to protect individuals against abuse by public authorities, including excessive amount of

\footnotetext{
9 Judgment of the Constitutional Tribunal of 5 May 2004, Ref. file: P 2/03.

10 Judgment of the Constitutional Tribunal of 4 July 2018, Ref. file: 16/16.

${ }^{11}$ M. Safjan, L. Bosek, Konstytucja RP, vol. 1. Komentarz do art. 1-86. Komentarz do art. 42, Warszawa 2016.
} 
judges' discretion and the manner of executing the consequences of prohibited acts, incommensurability of these consequences to guilt and punishment deed. ${ }^{12}$

The formula used for calculating the value of the fine in cases of non-fulfilment of the obligation of the NRT is:

$\mathbf{K}=\mathbf{S} \times \mathbf{O} \times \mathbf{W}$, where the individual symbols mean:

$\mathbf{K}$ - the amount of the fine, expressed in PLN [PLN];

$\mathbf{S}$ - the average price of greenhouse gas emission allowances listed on the ICE / ECX and EEX exchanges on the secondary spot market on the last day of the trading of emission allowances preceding the last day of the year in which the entity failed to fulfil its obligation under Art. 30b para. 1, converted into PLN according to the average euro exchange rate announced by the National Bank of Poland on this day, expressed in PLN per tonne of carbon dioxide equivalent [PLN / tCO2eq];

$\mathbf{O}$ - the value of the outstanding obligation referred to in Art. 30b section 1, expressed in tons of carbon dioxide equivalent per unit of energy [tCO2eq / MJ], with an accuracy of six decimal places;

W - the value corresponding with the calorific value or energy value of any liquid or liquid fuel consumed, liquid biofuels, liquefied gas (LPG), compressed natural gas (CNG) or liquefied natural gas (LNG) and electricity sold to the final recipient or used for one's own needs, calculated for the year in which the entity did not fulfil the obligation under Art. $30 \mathrm{~b}$ section 1 , expressed in energy units [MJ]. ${ }^{13}$

In the context of the above, it should be pointed out that the value of "O" from the formula can be reasonably predicted by the entitles fulfilling the NRT as they include such value in their forecasts. The value of "W" should also be possible to predict with a smaller degree of accuracy but the changes shouldn't be too significant. However, the value of "S" which refers to the stock price of the permission to emit greenhouse gases on ICE/ECX and EEX can be very hard to predict, as the stock exchange, due to its characteristics, is unpredictable to a significant degree. This variable is the most dubious, because it is independent of the actions of the entity not realising the reduction obligation imposed on it.

Thus, without carrying out detailed technical analyses regarding the possibility of determining the value of "O" and "W," as part of the legal analysis only, is rather likely, however the value of "S" seems to have the greatest impact on the possibility of making the thesis that the penalty, under Art. 35c section 3 of the Act, does not meet the principle of the specificity of the penalty, and thus could be possibly a penalty that breaks the guarantees provided to each entity pursuant to Art. 42 para. 1 of the Constitution of the Republic of Poland. ${ }^{14}$

It should be pointed out that the fine under Art. 35c section 3 of the Act was introduced only through the amendment of the Act made as a result of the entry

12 Judgment of the Constitutional Tribunal of 4 July 2018, Ref. Acts: 16/16 together with the mentioned case-law of the Constitutional Tribunal, in particular the Judgment of the Constitutional Tribunal of 26 November 2003, Ref. file: SK 22/02.

${ }^{13}$ Art. 35 c section 3 of the Act of 25 August 2006 on the fuel quality monitoring and control system.

${ }^{14}$ Constitution of the Republic of Poland of 2 April 1997 (Journal of Laws No. 78, item 483, as amended). 
into force of the Act of 11 July 2014 amending the act on the system for monitoring and controlling the quality of fuels and certain other acts. Earlier the Act did not include a provision for fines for non-performance of reduction duties. In the governmental draft, which was submitted to the parliament on 17 January 2014, the value of "S" was defined as the rate of 0.02 , expressed in PLN, per gram equivalent to carbon dioxide [PLN / gCO2eq]. ${ }^{15}$

The procedure for changing the component of determining the value of "S" proceeded without any discussion, and the MP proposing amendments to the Act justified the introduction of the change with the need to "make the calculation of the penalty more flexible and with reference to the price of $\mathrm{CO}_{2}$ emissions," ${ }^{16}$ however no analysis was made as to whether the proposed change is compatible with the principle of punishment specificity ensured in the Constitution of the Republic of Poland. Moreover, in the justification for amending the Act, it is impossible to find reasons why it was considered that just such a method of calculating the penalty is considered justified.

The doctrine emphasises that the level of penalty specification at the statutory level, resulting from the nulla poena sine lege certa principle, depends on the type of punishment, and thus on the manner and nature of limiting constitutional rights or freedoms, in particular the level of interference in the individual's good. The more severe the interference is, the stronger must be the guarantees that protect the individual against abuse of power, and thus - to a more detailed extent, the punishment must be characterised in the act. ${ }^{17}$

If, then, the penalty under Art. $35 \mathrm{c}$ of the Act, which potentially threatens the entity for non-performance of the obligation under Art. 30b section 1 of the Act is a penalty that may significantly interfere with the finances of a given entity $(15 \%$ of the penalised entity's income), it is necessary that the methods of calculating the potential penalty should be defined in a manner that can be understood by that entity.

Thus, even if some of the variables used to calculate the amount of the penalty threatening the entity are impossible to calculate before the time when the conditions justifying the imposition of the penalty (failure to fulfil the obligation under Art. 30b section 1 of the Act) are met, there are grounds for questioning the structure adopted so far defining the penalty, and consequently there are grounds for recognising that the punishment specified in this way does not fulfil the constitutional principle of punishment specificity.

However, before any entity is imposed with a financial penalty based on Art. $35 \mathrm{c}$ section 3 of the Act and therefore, there is a violation of rights, they do not have the right to submit to the Constitutional Tribunal a motion to examine the

15 Government bill amending the act on the system of monitoring and controlling the quality of fuels and amending the act on biocomponents and liquid biofuels. Print No. 2087.

16 Ibidem.

17 M. Safjan, L. Bosek, op. cit. 
constitutionality of Art. $35 \mathrm{c}$ section 3 of the Act. The entities will be entitled to submit a constitutional complaint only when the appeal route is exhausted. In such a case, the constitutional complaint may be brought before the Constitutional Tribunal after the legal proceedings have been exhausted within 3 months from the delivery of the final judgment, final decision or another final conclusion to the applicant. Therefore, as of today only entities listed in Art. 191 section 1 of the Constitution of the Republic of Poland are entitled to initiate proceedings in the subject of examining compliance with the Constitution of the Republic of Poland and these entities are: 1) the President of the Republic of Poland, 2) the Speaker of the Sejm, 3) the Speaker of the Senate, 4) the Prime Minister, 5) 50 MPs, 6) 30 senators, 7) First President of the Supreme Court, 8) President of the Administrative Supreme Court, 9) General Prosecutor, 10) President of the Supreme Chamber of Control, 11) Ombudsman.

On the other hand, if the technical and economic analyses show that entities obliged by the NRT are able to determine in advance the amount of the potential penalty for non-compliance with reduction obligations in a given calendar year, it should be considered that the penalty under Art. 35c section 3 of the Act meets the requirement of specificity of punishment, resulting from Art. 41 section 1 of the Constitution of the Republic of Poland.

\section{Additional issues}

The NRT is another legal requirement causing an increase in the operating costs of fuel producers in Poland. Also, fuel companies in Poland do not affect the amount of greenhouse gas emissions arising from the extraction of crude oil, because they do not have their own extraction facilities, which makes it impossible to use the relevant provisions of the Act.

In Poland, alternative fuels, in particular natural gas (LNG and CNG) and electric vehicles are not widespread due to the lack of appropriate infrastructure, and therefore there is a risk of transferring responsibility for building infrastructure onto fuel companies. ${ }^{18}$

\section{Conclusion}

The Act on the fuel quality monitoring and control system is very important and much needed - the aim of it is fundamental and it is to save the environment by reduction of greenhouse gas emissions. The $6 \%$ goal seems to be very optimistic, however it is not impossible to achieve. The problem with this Act and the Directive is that it imposes very harsh fines on the entities that do not manage to fulfil the NRT without imposing any responsibility on the Member States to provide the appropriate and required infrastructure and to also be punished for not meeting the goals. The

${ }^{18}$ P. Szpakowski, op. cit. 
entities are also obliged to prepare and provide to the President of the ERO an annual report, however the fines for failing this obligation are marginal. The entitles are able to fulfil the NRT together as a group, with provides them the opportunity to mitigate the differences with a greenhouse gas emissions indicator. The fine for failing to fulfil the NRT obligation is very harsh, but also it is quite uncertain without thorough technical and economical analyses, which may result in the provision being unconstitutional. The Act is aimed at achieving a very important goal; however, it may need a few changes to make it more specific.

\section{References}

Act of 25 August 2006 on the fuel quality monitoring and control system (i.e. Journal of Laws of 2019, item 660).

Consolidated versions of the Treaty on the European Union and the Treaty on the Functioning of the European Union (2012/C 326/01).

Constitution of the Republic of Poland of 2 April 1997 (Journal of Laws No. 78, item 483, as amended).

Directive 2009/30/EC of the European Parliament and of the Council of 23 April 2009 amending Directive 98/70/EC as regards the specification of petrol, diesel and gas-oil and introducing a mechanism to monitor and reduce greenhouse gas emissions and amending Council Directive 1999/32/EC as regards the specification of fuel used by inland waterway vessels and repealing Directive 93/12/EEC.

Government bill amending the act on the system of monitoring and controlling the quality of fuels and amending the act on biocomponents and liquid biofuels. Print No. 2087.

Judgment of the Constitutional Tribunal of 5 May 2004, Ref. file: P 2/03.

Judgment of the Constitutional Tribunal of 4 July 2018, Ref. file: 16/16.

Judgment of the Constitutional Tribunal of 4 July 2018, Ref. Acts: 16/16 together with the mentioned case-law of the Constitutional Tribunal, in particular the Judgment of the Constitutional Tribunal of 26 November 2003, Ref. file: SK 22/02.

Judgment of the Supreme Administrative Court of 24 February 2011, Ref. file: II GSK 257/10.

Judgment of the Voivodship Administrative Court in Warsaw of 18 November 2011, Ref. file: VI SA/Wa 1425/11.

Order of the Voivodship Administrative Court in Warsaw of 27 June 2013, Ref. file: VI SA/Wa 946/13.

\section{Secondary sources}

Gardocki L., Prawo karne, 9th ed., Warszawa 2003.

Safjan M., Bosek L., Konstytucja RP, vol. 1. Komentarz do art. 1-86. Komentarz do art. 42, Warszawa 2016.

Szpakowski P., "Narodowy Cel Redukcyjny z perspektywy podmiotu zobligowanego do jego realizacji," https://docplayer.pl/10486856-Narodowy-cel-redukcyjny-z-perspektywy-podmiotu-zobligowanego-do-jego-realizacji.html. 